УДК 616.314-007-053

DOI 10.11603/2311-9624.2020.1.11223

(В. С. Мельник, Л. Ф. Горзов, Я. І. Дуганчик, Б. Я. Сапович, Р. О. Халак

ДВН3 «Ужгородський національний університет»

e-mail: volodymyr.melnyk@uzhnu.edu.ua

\title{
Поширеність зубощелепних аномалії та удосконалення організації профілактичної роботи серед школярів
}

\section{ІНФОРМАЦІЯ}

Надійшла до редакціï/Received: 03.02.2019 p.

Ключові слова: школярі; зубощелепні аномалії; організація профілактичної роботи.

\section{АНОТАЦІЯ}

Резюме. За даними багатьох досліджень, поширеність зубощелепних аномалій (ЗЩА) в структурі стоматологічної захворюваності стоїть на третьому місці після карієсу зубів і патології тканин пародонта. Функціональні розлади та ортодонтичні порушення зубощелепної системи є не тільки проблемою стану здоров'я людини, але і важливим аспектом в процесі формування особистості та соціального статусу.

Мета дослідження - вивчити поширеність зубощелепних аномалій та удосконалити організацію профілактичної роботи серед школярів у віці 14-15 років.

Матеріали і методи. Обстежено 268 дітей та підлітків: 122 хлопців (45,5 \%) і 146 дівчат (54,5 \%). Для верифікації діагнозу ЗЩА використовували класифікацію Д. А. Калвеліса, для оцінки потреби в ортодонтичному лікуванні використали клінічний індекс Index Of Treatment Need, призначений для визначення наявності та оцінки вираження зубощелепних аномалій безпосередньо при огляді пацієнта.

Результати досліджень та їх обговорення. У структурі видів патологічного прикусу найчастіше зустрічався глибокий $(38,0 \%)$, на другому місці знаходився перехресний тип (28,8 \%), 20,4 \% склав дистальний вид, 7,3 \% - прямий, 3,3 \% - відкритий, 2,2 \% - мезіальний. У 74,0 \% дітей була деформація зубних рядів. Найбільш часто (46,0 випадків на 100) - деформації нижнього зубного ряду, в 28,0 випадків на 100 - верхнього зубного ряду. У 58,0 \% дітей реєстрували скупчення зубів, в 23,4 \% випадків спостерігалася трема, а в 18,6 \% - діастема. Найчастіше скупчення зубів відзначалося в передньому відділі нижньої щелепи (44,4 випадка на 100 оглянутих), причому в дівчаток воно фіксувалося достовірно частіше. Рідше - в передньому відділі верхньої щелепи (16,1 на 100 оглянутих). Інші локалізації даної патології були рідко.

Висновки. В ході обстеження ротової порожнини було виявлено, що в більшості випадків у дітей 12-15 років спостерігалися аномалії розвитку зубів, що могло бути зумовлено як вродженими чинниками, так і впливом зовнішніх факторів. Всі подібні випадки повинні мати корекцію в ортодонта з метою ранньої профілактики як самих ортодонтичних порушень, так і їх наслідків, проте батьки не поспішають приводити дітей на прийом до ортодонта.
Вступ. У дослідженнях останніх років відзначено стійке зростання поширеності зубощелепних аномалій (ЗЩА), що за даними багатьох досліджень, займає третє місці після карієсу зубів і патології тканин пародонта [1-3].
Епідеміологічні стоматологічні обстеження свідчать про те, що частка дітей із ЗЩА становить близько 75 \% і має тенденцію до подальшого збільшення [4].

Функціональні розлади та ортодонтичні порушення зубощелепної системи є не тіль- 
ки проблемою стану здоров'я людини, але i важливим аспектом у процесі формування особистості та соціального статусу. Патології прикусу, які не виявлені й не усунуті в дитячому віці, в процесі росту і розвитку лицевого скелета $з$ часом набувають більш тяжких форм, що стають більш вираженими і гірше піддаються лікуванню [5].

Цілком очевидно, що домогтися зниження росту частоти зубощелепних аномалій можна тільки за умови їх профілактики та лікування, починаючи з дитячого віку.

Метою дослідження було вивчити поширеність зубощелепних аномалій та удосконалити організацію профілактичної роботи серед школярів у віці 14-15 років.

Матеріали і методи. У період 32015 до 2019 р. проведено комплексне медико-соціальне дослідження 3 вивчення поширеності зубощелепних аномалій та ретроспективний аналіз медичних карт 268 школярів м. Ужгород у віці 14-15 років - період постійного прикусу, які перебувають на ортодонтичному лікуванні в дитячому стоматологічному відділенні Університетської клінічної стоматологічної поліклініки Ужгородського національного університету.

Стоматологічне обстеження проводили співробітники кафедри дитячої стоматології стоматологічного факультету УжНУ разом із студентами V курсу. Лікарі та студенти, які брали участь у стоматологічному огляді, попередньо пройшли курс навчання (калібровки) для забезпечення стандартного підходу в діагностиці зубощелепних аномалій та видів прикусу.

Об'єктами обстеження були діти у віці 14-15 років, які навчаються у загальноосвітніх навчальних закладах м. Ужгород. Тільки діти та підлітки, чиї батьки підписали інформовану згоду на обстеження, були включені до вибірки. Критеріями виключення були: не підписання інформованої згоди та діти з особливими потребами.

Стоматологічне обстеження проводилося відповідно до рекомендацій ВОО3 за традиційною схемою 3 поглибленим вивченням ортодонтичного статусу в умовах стоматологічного кабінету з урахуванням основних положень Гельсінської декларації з біомедичних досліджень (Сеул, 2008) [6].

Дані клінічних спостережень фіксували в картах обстеження стану ротової порожнини. Всього обстежено 268 дітей та підлітків: 122 хлопців (45,5 \%) і 146 дівчат (54,5 \%). Що стосується їх віку, то середнє значення становило $(14,54 \pm 0,37)$ року з числа практично здорових дітей, які постійно проживають в даній місцевості.

Для верифікації діагнозу ЗЩА використовували класифікацію Д. А. Калвеліса [7]. Для оцінки потреби в ортодонтичному лікуванні застосовували клінічний індекс Index of Treatment Need (IOTN), описаний Brook and Shaw (1989) і модифікований Richmond (1990), який поєднує в собі естетичні компоненти (AC) та компоненти стоматологічного здоров'я (DHC), призначений для визначення наявності та оцінки вираження зубощелепних аномалій безпосередньо при огляді пацієнта [8, 9].

Статистичну обробку результатів проводили з використанням пакета комп'ютерної програми Microsoft Excel 2010. Результати опрацьовано статистично 3 використанням t-критерію Стьюдента [10].

Результати досліджень та їх обговорення. За результатами огляду, більше половини школярів мали обличчя середнього типу (по ширині, 53,9 \%) трикутної форми (43,2%) і мали прямий профіль (50,2 \%). Асиметрія обличчя спостерігалася лише в п'яти випадках. У 62,6 \% випадків виступ підборіддя був нормальним, проте в 21,9 \% випадків відзначалося зменшення виступу, а в $15,5 \%$ - збільшення. У 81,7 \% спостережень нижня частина обличчя дітей була в нормі, у 12,6 \% відзначалося подовження нижньої третини обличчя, а в 5,7 \% випадків - вкорочення. 88,6 \% дітей мали носовий характер дихання. За усіма вказаними ознаками достовірних гендерних відмінностей не було виявлено.

У ході вивчення стану скронево-нижньощелепного суглоба було виявлено, що в більшості (97,0 \%) випадків відкриття рота у школярів було безболісним, і все ж 2,0 \% дітей відчували біль, $1 \%$ мали складнощі при відкритті рота. У дівчаток ці симптоми зустрічалися в 2 рази частіше, ніж у хлопчиків.

У 13,2 \% дітей відзначався хруск при рухах нижньої щелепи, в 12,2 \% - клацання, в рівному співвідношенні як справа, так і зліва. У 23,6 \% спостережень губи були надмірно стиснуті, у 16,6 \% - привідкриті. Вираження носогубних складок знижене у 35,9 \% оглянутих, підвищене - в кожному десятому випадку (10,8 \%).

Мовотворення було визнано задовільним лише у половини школярів (56,8 \%). Порушення мови становили: у 21,8 \% дітей - порушен- 
ня вимови літери «р», у 7,9 \% - свистяча мова, 7,0 \% - переважання шиплячих звуків, 5,3 \% - порушення вимови літери «л», 1,2 \% - невиразна мова.

Середнє число шкідливих звичок склало 1,99 на 1 дитину, 3 них 1,89 припадало на 1 хлопчика, 2,07 - на 1 дівчинку (різниця не була статистично достовірною). Найбільш поширеною шкідливою звичкою у дітей було споживання насіння (53,8 на 100 оглянутих), також досить високими були рівні таких звичок, як прикушування нижньої губи (44,6 на 100), звичка гризти нігті (31,4 на 100) та ручку (30,1 на 100). Прикушують щоки 19,8 школярів з 100, верхню губу - 14,1. Найбільш рідкісними були звички смоктати ручку і смоктати палець (3,9 і 1,6 відповідно).

Серед оглянутих дітей 17,8 \% отримували ортодонтичне лікування, причому, дівчатка проходили лікування достовірно частіше від

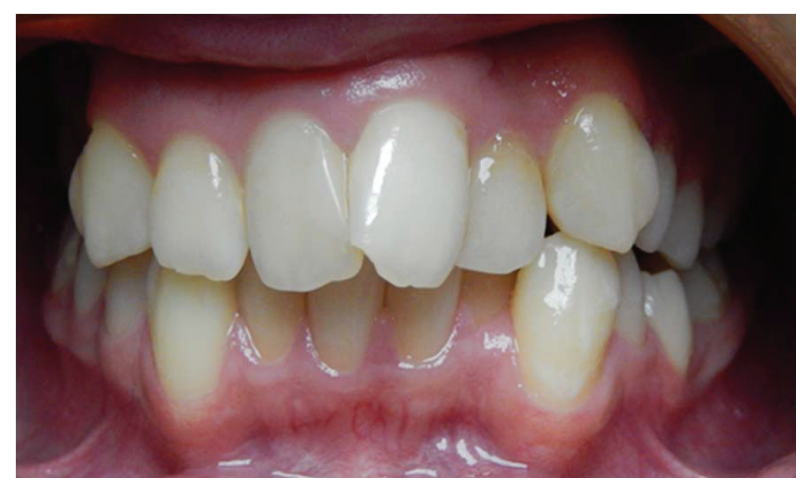

Puc. 1. Скупчення зубів.

Кожній 11 дитині вуздечка заважала руху язика. У третини випадків (34,5 \%) прикус був визнаний патологічним, причому 3 віком частка школярів із порушенням прикусу збільшувалася: якщо у віковій групі до 7 років частка таких школярів становила 27,7 \%, то до 15 років вона доходила до 38,8 \%.

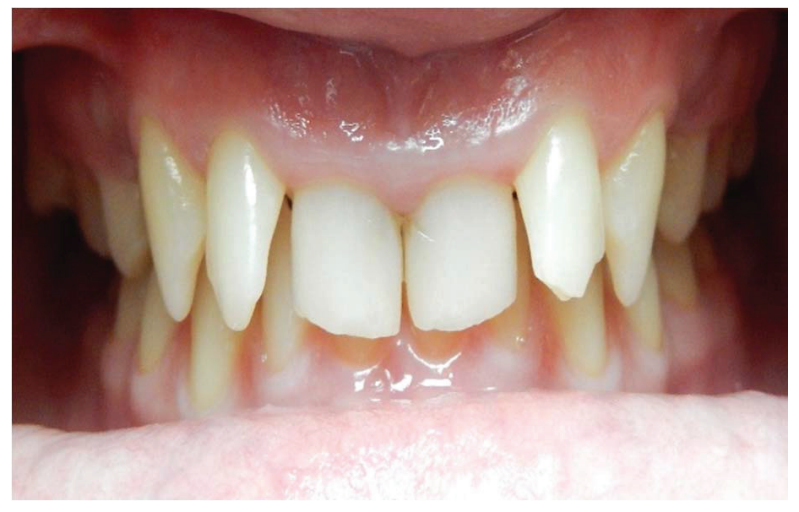

Puc. 3. Глибокий прикус.

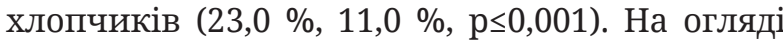
у фахівця на момент обстеження побувало 27,1\% школярів. Решта 72,9 \% дітей жодного разу не була в ортодонта, хлопчики - достовірно рідше, ніж дівчатка.

Тим часом, у 74,0 \% дітей відзначалася деформація зубних рядів. Найбільш часто (46,0 випадків на 100) - деформації нижнього зубного ряду, в 28,0 випадків на 100 - верхнього зубного ряду.

У 58,0 \% дітей реєстрували скупчення зубів (рис. 1), в 23,4 \% випадків спостерігалася трема, а в 18,6 \% - діастема (рис. 2). Найбільш часто скупчення зубів відзначалося в передньому відділі нижньої щелепи (44,4 випадка на 100 оглянутих), причому в дівчаток воно фіксувалося достовірно частіше. Рідше - в передньому відділі верхньої щелепи (16,1 на 100 оглянутих). Інші локалізації даної патології зустрічалися рідко.

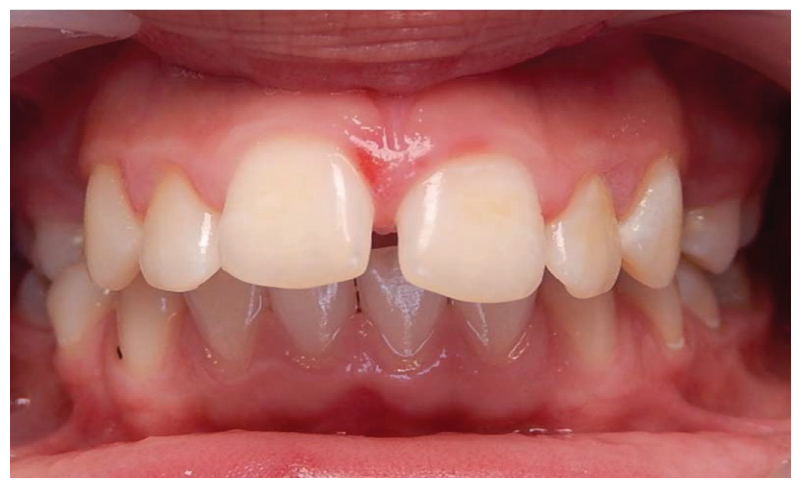

Puc. 2. Діастема, дистальний прикус.

У структурі видів патологічного прикусу найбільш часто зустрічався глибокий $(38,0$ \%) (рис. 3), на другому місці знаходився перехресний тип (28,8 \%) (рис. 4), 20,4 \% склав дистальний вид (рис. 2), 7,3 \% - прямий, 3,3 \% - відкритий (рис. 5), 2,2 \% - мезіальний (рис. 6).

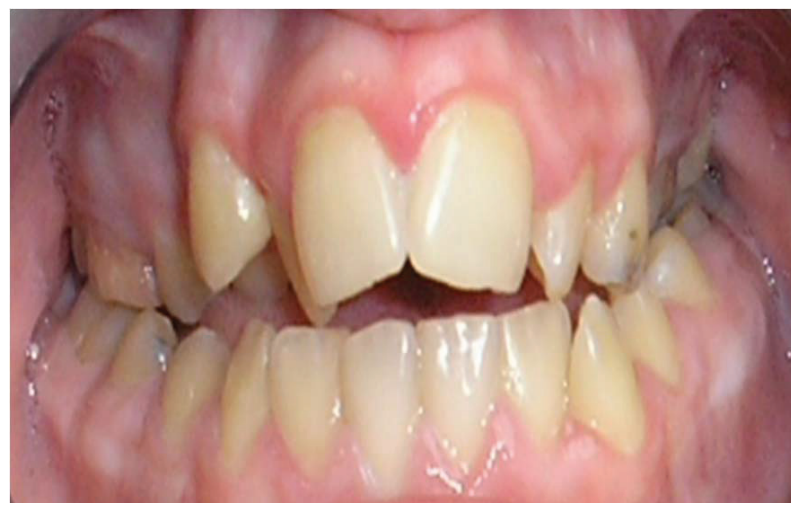

Puc. 4. Перехресний прикус. 


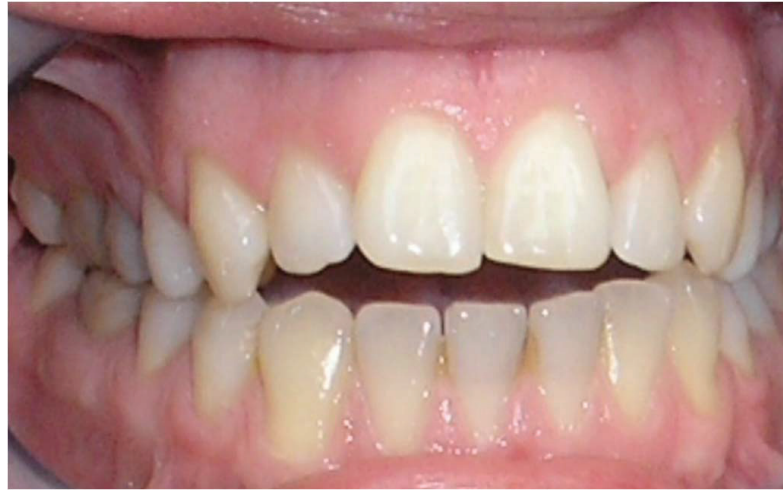

Puc. 5. Відкритий прикус.

При оцінці середньої лінії обличчя було встановлено, що менш ніж у половини дітей $(47,9 \%)$ воно було в нормі. У решти випадках середня лінія його була зміщена, причому в 35,9 \% зміни стосувалися нижнього зубного ряду, а в 16,2 \% - верхнього. Серед хлопців нормальний стан зустрічався достовірно частіше, ніж у дівчат $(\mathrm{p} \leq 0,01)$. Величина зміщення середньої лінії обличчя в основному коливалася від 0,1 мм до 3,0 мм.

Найбільш поширеними відхиленнями від норми у розвитку зубів у школярів були виявлені аномалії розміру зубів (5,3 випадка на 100 оглянутих) і аномалії положення зуба, де на кожного школяра в середньому доводилося по 6,1 зуба аномальної форми.

Серед аномалій розмірів зубів найчастіше відзначали мікродентію (4,3 випадка на 100 оглянутих).

Аномалії положення зубів найчастіше спостерігалися на різцях (154,2 випадка на 100 оглянутих). Ікла були аномально розміщені в 93,8 випадка на 100 оглянутих. У 87,3 випадка на 100 оглянутих відзначалися аномальні положення корінних зубів (премолярів і малярів).

У структурі аномалій положення зубів перше місце займала тортооклюзія (51,2 \%), на другому місці знаходилося оральне положення зубів (19,9 \%), на третьому - вестибулярне

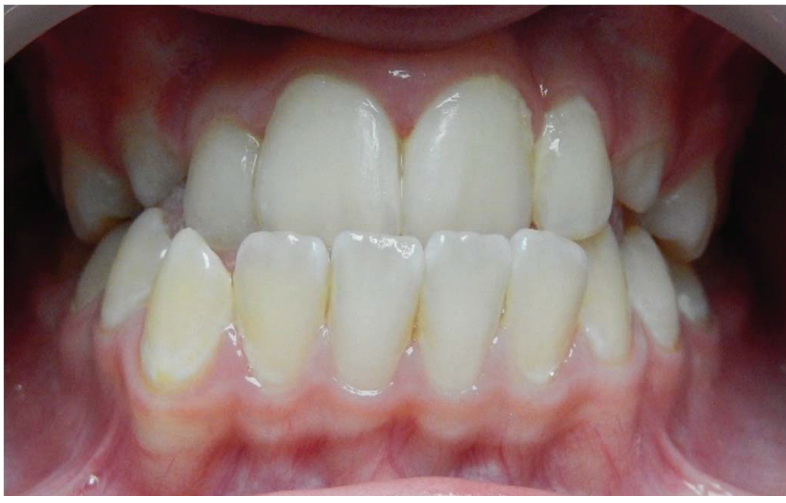

Puc. 6. Мезіальний прикус.

положення зубів (11,8 \%), на четвертому - мезіальне $(6,8 \%)$, за ними йшли дистооклюзія $(6,1 \%)$, супраоклюзія $(3,0 \%)$ та інфраоклюзія $(1,4 \%)$.

Висновки. У ході обстеження ротової порожнини було виявлено, що в більшості випадків у дітей 12-15 років спостерігалися аномалії розвитку зубів, що могло бути зумовлено як вродженими чинниками, так і впливом зовнішніх факторів. Усі подібні випадки повинні мати корекцію в ортодонта 3 метою ранньої профілактики як самих ортодонтичних порушень, так і їх наслідків, проте батьки не поспішають приводити дітей на прийом до ортодонта. Та й дитячі лікарі-стоматологи вкрай рідко направляють таких пацієнтів на відповідний прийом. Наші дослідження також показали, що рівень профілактичних знань батьків низький, так само і як їх медична активність.

Перспективи подальших досліджень. Резюмуючи вищевикладений матеріал, вважаємо за необхідне звернути особливу увагу на організацію профілактичної роботи в ортодонтії - як за участю фахівців (в т. ч. шкільних лікарів-стоматологів, які ще залишились), лікарів стоматологічних державних та приватних поліклінік із широким залученням батьків.

\section{Распространенность зубочелюстных аномалии и совершенствование организации профилактической работы среди школьников}

Резюме. По данным многих исследований, распространенность зубочелюстных аномалий (ЗЧА) в структуре стоматологической заболеваемости стоит на третьем месте после кариеса зубов и патоло- 
гии тканей пародонта. Функциональные расстройства и ортодонтические нарушения зубочелюстной системы являются не только проблемой состояния здоровья человека, но и важным аспектом в процессе формирования личности и социального статуса.

Цель исследования - изучить распространенность зубочелюстных аномалий и совершенствование организации профилактической работы среди школьников в возрасте 14-15 лет.

Материалы и методы. Всего обследовано 268 детей и подростков: 122 ребят (45,5 \%) и 146 девушек (54,5 \%). Для верификации результатов обследований ЗЧА использовали классификацию Д. А. Калвелиса, для оценки потребности в ортодонтическом лечении использовали клинический индекс Index Of Treatment Need, предназначен для определения наличия и оценки выраженности зубочелюстных аномалий непосредственно при осмотре пациента.

Результаты исследований и их обсуждение. В структуре видов патологического прикуса наиболее часто встречался глубокий (38,0 \%), на втором месте находился перекрестный тип (28,8 \%), 20,4 \% и составил дистальный вид, 7,3 \% - прямой, 3,3 \% - открытый , 2,2 \% - мезиальный. В 74,0 \% детей отмечалась деформация зубных рядов. Наиболее часто (46,0 случаев на 100) - деформации нижнего зубного ряда, в 28,0 случаев на 100 - верхнего зубного ряда. В 58,0 \% детей регистрировали скученность зубов, в 23,4 \% случаев наблюдалась трема, а в 18,6 \% - диастема. Наиболее часто скученность зубов отмечалась в переднем отделе нижней челюсти (44,4 случая на 100 осмотренных), причем у девочек оно фиксировалось достоверно чаще. Реже - в переднем отделе верхней челюсти (16,1 на 100 осмотренных). Другие локализации данной патологии встречались редко.

Выводы. В ходе обследования полости рта было обнаружено, что в большинстве случаев у детей $12-$ 15 лет наблюдались аномалии развития зубов, могло быть обусловлено как врожденными факторами, так и влиянием внешних факторов. Все подобные случаи должны иметь коррекцию у ортодонта с целью ранней профилактики как самих ортодонтических нарушений, так и их последствий, однако родители не спешат приводить детей на прием к ортодонту.

Ключевые слова: школьники; зубочелюстные аномалии; организация профилактической работы.

\author{
COV. S. Melnyk, L. F. Horzov, Ya. I. Duhanchyk, B. Ya. Sapovych, R. O. Khalak \\ Uzhhorod National University
}

\title{
Prevalence of dental anomalies and improvement of the organization of preventive work among schoolchildren
}

Summary. According to many studies, the prevalence of dentognathic in the structure of dental morbidity is in third place after dental caries and periodontal tissue pathology. Functional disorders and orthodontic disorders of the dental system are not only a problem of human health, but also an important aspect in the process of personality formation and social status.

The aim of the study - to learn the prevalence of dental anomalies and improve the organization of preventive work among schoolchildren aged 14-15 years.

Materials and Methods. A total of 268 children and adolescents were examined: 122 boys (45.5 \%) and 146 girls (54.5\%). To verify the diagnosis of dentohnathic anomalies used the classification of Calvelis, to assess the need for orthodontic treatment used a clinical index - Index of Treatment Need, designed to determine the presence and assessment of the severity of dental anomalies directly during the examination of the patient.

Results and Discussion. In the structure of the types of pathological occlusion the most common was deep $(38.0 \%)$, in second place was the cross type ( $28.8 \%), 20.4 \%$ was the distal type, $7.3 \%$ - direct, $3.3 \%$ - open , $2.2 \%$ - mesial. In $74.0 \%$ of children there was a deformation of the dentition. The most common (46.0 cases per 100) - deformations of the lower dentition, in 28.0 cases per 100 - the upper dentition. In $58.0 \%$ of children there was a congestion of teeth, in $23.4 \%$ of cases there was tremor, and in $18.6 \%$ - diastema. The most frequent congestion of teeth was observed in the anterior mandible (44.4 cases per 100 examined), and in girls it was recorded significantly more often. Less often - in the anterior part of the upper jaw (16.1 per 100 examined). Other localizations of this pathology were rare.

Conclusions. Thus, during the examination of the oral cavity it was found that in most cases in children 12-15 years there were abnormalities in the development of teeth, which could be due to both congenital factors and the influence of external factors. All such cases should be corrected by an orthodontist for the purpose of early prevention, both of the orthodontic disorders themselves and their consequences, but parents are in no hurry to bring their children to the orthodontist.

Key words: schoolchildren; dental anomalies; organization of preventive work. 


\section{СПИСОК ЛІТЕРАТУРИ}

1. Костенко Є. Я. Поширеність та структура зубощелепних аномалій у дітей Закарпатської області / $€$. Я. Костенко, В. С. Мельник // Науковий вісник Ужгородського університету. Сер. : Медицина. 2016. - Вип. 1. (53). - С. 102-105.

2. Лучинський М. А. Частота зубощелепних аномалій та деформацій у дітей різних адаптивних типів Прикарпаття / М. А. Лучинський // Вісник соціальної гігієни та організації охорони здоров'я України. - 2013. - № 1. - С. 31-34.

3. Міськів А. Л. Структура зубощелепних аномалій У дітей Львівської області / А. Л. Міськів, Е. В. Безвушко // Acta medica Leopoliensia. - 2015. - Т. 21, № 2. - C. 10-13.

4. Дорошенко С. І. Розповсюдженість зубощелепних аномалії та деформацій, а також дефектів зубів та зубних рядів серед дітей шкільного віку м. Києва / С. І. Дорошенко, Є. А. Кульгінський // Вісник стоматології. - 2009. - № 2. - С. 76-81.

5. Голованова I. А. Медико-соціальне обгрунтування оптимізованої моделі надання ортодонтичної допо-

\section{REFERENCES}

1. Kostenko, Ye.Ia., \& Melnyk, V.S. (2016). Poshyrenist ta struktura zuboshchelepnykh anomalii u ditei Zakarpatskoi oblasti [Prevalence and structure of dentognathic anomalies in children of Transcarpathian region]. Naukovyi visnyk Uzhhorodskoho universytetu. Ser.: Medytsyna - Scientific Bulletin of Uzhhorod University. Ser.: Medicine, 1 (53), 102-105 [in Ukrainian]. 2. Luchynskyi, M.A. (2013). Chastota zuboshchelepnykh anomalii ta deformatsii u ditei riznykh adaptyvnykh typiv Prykarpattia [Frequency of dentognathic anomalies and deformations in children of different adaptive types of Precarpathia]. Visnyk sotsialnoi hihiieny ta orhanizatsii okhorony zdorovia Ukrainy Bulletin of Social Hygiene and Organization of Protection of Health of Ukraine, 1, 31-34 [in Ukrainian].

3. Miskiv, A.L., \& Bezvushko, E.V. (2015). Struktura zuboshchelepnykh anomalii u ditei Lvivskoi oblasti [The structure of dentognathic anomalies in children of Lviv region]. Acta medica Leopoliensia, 21, 2, 10-13 [in Ukrainian].

4. Doroshenko, S.I. \& Kulhinskyi, Ye.A. (2009). Rozpovsiudzhenist zuboshchelepnykh anomalii ta deformatsii, a takozh defektiv zubiv ta zubnykh riadiv sered ditei shkilnoho viku m. Kyieva [The prevalence of dentognathic anomalies and deformations, and defects in teeth and dentition among children of school age in Kyiv]. Visnyk stomatolohii - Bulletin of Dentistry, 2, 7681 [in Ukrainian]. моги дитячому населенню на регіональному рівні / I. А. Голованова, Н. О. Ляхова // Економіка і право охорони здоров’я. - 2018. - № 2 (8). - С. 11-16.

6. Стоматологическое обследование, основные методы. - 3-е изд. : бюллетень ВОЗ. - Женева, 1989. $-21 \mathrm{c}$.

7. Orthodontics. Dentognathic Anomalies and Deformations: textbook (IV a. l.) / P. S. Flis, H. P. Leonenko, V. V. Filonenko, N. M. Doroshenko ; edited by P. S. Flis. - 2nd edition, corrected. Всеукр. Специализ. изд-во «Медицина», 2016. - С. 176.

8. Daniels C. The development of the index of complexity, outcome and need (ICON) / C. Daniels, S. Richmond // Jю Orthod. - 2000. - Vol. 27 (2). - P. 149-162.

9. Grainger R. M. Orthodontic Treatment Priority Index, Public Health Service Publication 1967. No. 1000, Series 2, No. 25, US Government Printing Office, Washington DC.

10. Біостатистика / [В. Ф. Москаленко, О. П. Гульчій, М. В. Голубчиков та ін.]. - К. : Книга плюс, 2009. $184 \mathrm{c}$.

5. Golovanova, I.A., \& Lyakhova, N.O. (2018). Medykosotsialne obhruntuvannia optymizovanoi modeli nadannia ortodontychnoi dopomohy dytiachomu naselenniu na rehionalnomu rivni [Medico-social substantiation of the optimized model of rendering orthodontic care to the child population at the regional level]. Ekonomika i pravo okhorony zdorovia-Economics and Healthcare Law, 2 (8), 11-16 [in Ukrainian].

6. (1989). Byulleten WHO "Stomatologycheskoe obsledovanye, osnovnye metody" [Dental examination, basic methods]. Zheneva [in Russian].

7. Flis, P.S., Leonenko, H.P., Filonenko, V.V., \& Doroshenko, N.M. (2016). Orthodontics. Dentognathic Anomalies and Deformations: textbook (IV a. l.). Flis, P.S. (Ed.). All-Ukrainian Specialty publishing house "Medicine".

8. Daniels, C., \& Richmond, S. (2000). The development of the index of complexity, outcome and need (ICON). $J$. Orthod., 27 (2), 149-162.

9. Grainger, R.M. (1967). Orthodontic Treatment Priority Index. Public Health Service Publication. No. 1000, Series 2, No. 25, US Government Printing Office, Washington DC.

10. Moskalenko, V.F., Hulchii, O.P., Holubchykov, M.B., Lyedoshhuk, B.O, Lyexan, V.M., Ohnyev, V.A., ..., \& Tonkovyd O.B. (2009). Biostatystyka [Biostatistics]. Kyiv: Knyha plius [in Ukrainian]. 